\title{
Document details - Independent campus on industrial engineering undergraduate program in Indonesia: A delphi method
}

1 of 1

$\rightarrow$ Export $\Perp$ Download More...>

Cited by 1 document

Yusuf, F.A.

The independent campus program for higher education in indonesia: The role of government support and the readiness of institutions, lecturers and students

2020 IEEE International Conference on Industrial Engineering and Engineering Management, IEEM 2020; Virtual, Singapore; Singapore; 14 December 2020 through 17 December 2020; Category numberCFP20IEI-ART; Code 166486

Independent campus on industrial engineering undergraduate program in Indonesia: A delphi method(Conference Paper)

Lestari, F., Kusumanto, I., Hasri, S., Akmaluhadi

aUIN Sultan Syarif Kasim, Department of Industrial Engineering, Riau, Indonesia

${ }^{b}$ Faculty of Education and Teacher Training, UIN Sultan Syarif Kasim, Riau, Indonesia

${ }^{c}$ Marketing Coordinator, Citraciti Pasific, Riau, Indonesia

Abstract

The industrial engineering department needs to evaluate graduates who can adapt their expertise to the needs of the industry. The purpose of this study is to assess graduate skills through program educational objectives (PEO) and learning outcomes (LO) and propose an undergraduate student internship program by adopting the concept of an independent campus in Indonesia. Moreover, it also uses a three-round the Delphi method through the in-depth interviews with 128 alumni in 100 industries, focus group discussion with ten experts, and validation from the panelist consist of practitioner and academician. Findings presented that 3 PEO and 14 LO still relevant based on the industrial requirement. Then, this study found that there were two types of internship programs consisting of 18 skills of the internship program in the industry and 14 skills of the entrepreneurship program. The paper guides the industrial engineering department in charge of an undergraduate student internship program through a Delphi method. (c) 2020 IEEE.

SciVal Topic Prominence (i)

Topic: Hospitality Management | Tourism and Hospitality | Leadership Competencies

Prominence percentile: $\quad 72.524$

(i)

Author keywords

Delphi method Independent campus Industrial engineering department Internship program

Indexed keywords

Engineering controlled Apprentices Students

terms:

Engineering uncontrolled

terms

Engineering undergraduates Entrepreneurship programs In-depth interviews Industrial requirements

Internship programs Learning outcome Program educational objectives Undergraduate students

Engineering main

heading:

Engineering education

Funding details

Funding text

The authors thanks to the Ministry of Religious Affairs Republic of Indonesia and Sultan Syarif Kasim State Islamic University, which supported this research.
(2021) Journal of Social Studies Education Research

View details of this citation

Inform me when this document is cited in Scopus:

Set citation alert > Set citation feed >

Related documents

Find more related documents in Scopus based on:

Authors > Keywords >
ISSN: 21573611

ISBN: 978-153867220-4

Source Type: Conference Proceeding

Original language: English
DOI: 10.1109/IEEM45057.2020.9309800

Document Type: Conference Paper

Publisher: IEEE Computer Society 
About Scopus

What is Scopus

Content coverage

Scopus blog

Scopus API

Privacy matters
日本語に切り替える

切换到简体中文

切換到繁體中文

Русский язык

Customer Service

ELSEVIER

Terms and conditions $\pi \quad$ Privacy policy $\pi$

Copyright $\odot$ Elsevier B.V $\boldsymbol{\lambda}_{\text {. }}$. All rights reserved. Scopus ${ }^{\circledR}$ is a registered trademark of Elsevier B.V.

We use cookies to help provide and enhance our service and tailor content. By continuing, you agree to the use of cookies.

Q RELX

Help

Contact us 